\title{
Радован Поповић
}

\section{Разматрање формално- композиционих карактеристика оријенталистичких слика Паје Јовановића}

UDC 75.071.1:929 Jovanović P. UDC 75.036

Апстракт. Сликарство Паје Јовановића формирало се у свим својим најважнијим карактеристикама током друге половине седамдесетих и прве половине осамдесетих година XIX века, оном временском распону у историји европске уметности који има значај конститутивног периода за настанак сликарских поетика као што су импресионизам, пленеризам, поентилизам и симболизам, које су у погледу композиције, колорита и употребе светлости темељно трансформисали миметичке обрасце и традиционалне поступке атељејског приступа моделу и извели сликарство из традиране самонаметнуте изолације у пулсантну стварност природних стихија и људских страсти, већ тада одређену не само вековном тематиком кристализованом у „вечним“ сукобима дужности и части, љубави и самоодрицања, индивидуалног аривизма и алтруистичке преданости, него све више и диктатом осамостаљеног и техницизованог разума, који је још крајем XVIII века започео свој победоносни ход ка овладавању и искоришћавању свих расположивих извора скривених у некада сакрализованој природи, руководећи се бејконовском формулом знање је моћ. Многобројна путовања по оријентализованим крајевима Балканског полуострва, те студијска путовања на Кавказ и у Египат, пружила су Паји Јовановићу непосредан увид у неисцрпно обиље иконографских детаља и мотивске грађе која је касније унета у његова оријенталистичка дела.

Кључне речи: оријентализам, Балкан, импресионизам, композиција, колорит

Сликарство Паје Јовановића формирало се у свим својим најважнијим карактеристикама током друге половине седамдесетих и прве половине осамдесетих година XIX века, оном временском распону у историји европске уметности који има значај конститутивног периода за настанак сликарских поетика као што су импресионизам, пленеризам, поентилизам и симболизам, које су у погледу композиције, колорита и употребе светлости темељно трансформисали 
миметичке обрасце и традиционалне поступке атељејског приступа моделу и извели сликарство из традиране самонаметнуте изолације у пулсантну стварност природних стихија и људских страсти, већ тада одређену не само вековном тематиком кристализованом у „вечним“ сукобима дужности и части, љубави и самоодрицања, индивидуалног аривизма и алтруистичке преданости, него све више и диктатом осамостаљеног и техницизованог разума, који је још крајем XVIII века започео свој победоносни ход ка овладавању и искоришћавању свих расположивих извора скривених у некада сакрализованој природи, руководећи се бејконовском формулом знање је моћ. И док је импресионизам експериментисао с растапањем чврстих пластичких форми у несводивом субјективном оптичком утиску, у коме луминозност предмета, његов специфичан валер задобија предност над бојом која се сматра исувише везаном за обојену површину да би произвела непосредност и једнократност доживљаја1, симболизам и прерафаелитизам захтевају да сликарство постане експресивни медиј симболизаторске делатности као најсвојственије особине људског бића, те да се ти симболички садржаји, похрањени у сновима, митовима, колективним предањима и ранохришћанској религиозности, представе у једноставности сликарске технике и тематског круга уметности средњег века и ране ренесансе (,пре Рафаела“)2. Задаци које су ови нови токови ликовне уметности поставили сликарству друге половине XIX века наишли су готово без изузетка на отпор институционализованог академског реализма и у високошколским образовним установама у којима су традиције реалистичког сликарства биле дубоко укорењене. Управо у једној изразито традиционалистички оријентисаној средини - Академији ликовних уметности у Бечу - формирао је, тако да касније никада од њега озбиљније не одступи, Паја Јовановић свој сликарски credo, који се углавном исцрпљивао у ставу да уметност треба да представља верно преношење предмета и појава опажених у тродимензионалном простору у пиктурални простор, тако да, како је и сам једном изјавио, слика којој уметник даје назив нема уметничку вредност; гледалац, наставља он, треба да без наслова чита шта она прича. Паја Јовановић, све док већ није било касно,

1 'Светлина' је мера количине видљиве светлости коју ка посматрачу упућује хомогена површина чврстог тела. Тај термин може без оклеваға да се замени можда непосредније сугестивним термином 'луминозност'. У предметима идентичним у сваком погледу, флукс видљиве светлости који продире у око посматрача директно је пропориионалан светлини повриине коју посматра... Ако, међутим, обратимо пажњу на две суседне повриине од којих једна има двоструко јачу светлину, ьена ретинална слика такође добија и два пута више светлости. Јасно је да овде није у питану боја две повриине, него једино оно што сликари називају ьиховим валером, тј. ниховом већом или мағом јасноћом - Charles Lapique. (1958). Recherches scientifiques sur les valeurs et les couleurs dans leurs rapports avec la création picturale; u: Essais sur l'espace, l'art et la destinée. Paris: Éditions Bernard Grasset, pp. 233-234. Cf. Pierre Francastel. (1964).Umetnost i tehnika. Beograd: Nolit, pp. 112-151;

2 Cf. Pierre Francastel. (1965) Peinture et société. Paris: Gallimard, pp. 109-177. 
односно док већ није постао зрео уметник с изграђеним погледом на средства и циљеве сликарства, свој несумњив таленат обликовао је у провинцијалној средини, која се налазила на далекој маргини радикалних преображаја кроз које је у то време пролазила уметност у Европи. Знања која је могао да стекне код приватног учитеља сликања у родном Вршцу, а затим на припремном курсу за упис на Академију код Махолца (Maholz) нису могла да му пруже много више од техничких упутстава и сликања у традицији репрезентативних портрета и жанр-сликарства по класичним узорима ${ }^{3}$, што је изгледа оставило дубок траг код Јовановића у његовим каснијим реминисценцијама на Ватоа (François Vateau). Школовање под стручним надзором Кристијана Грипенкерла (Christian Grippenkerl), осим значаја који је имало у стицању професионалног статуса академског сликара, није остварило већи утицај на каснију преферентну тематску оријентацију, коју је Јовановић преузео од сликара и педагога код кога је похађао курс тзв. историјског сликарства - Карла Леополда Милера (Carl Leopold Müller). Милер је тада био сликар „оријенталних тема“ међународне репутације, који је, упућујући своје студенте на бележење сцена из свакодневног живота у крајевима из којих су потицали, свакако тежио и извесном ликовно-представном уобличењу геополитичког простора Аустро-Угарске, али је можда у још већој мери допринео и конституисању националне свести народа̂ под хабсбуршким суверенитетом. Многобројна путовања по оријентализованим крајевима Балканског полуострва, те студијска путовања на Кавказ и у Египат, пружила су Паји Јовановићу непосредан увид у неисцрпно обиље иконографских детаља и мотивске грађе која је касније унета у његова оријенталистичка дела. Међутим, Оријент који је нашао место на Јовановићевим сликама, а у традицији немачко-аустријског оријенталистичког сликарства, представља углавном његов малоазијско-балкански модалитет, далеко од преовлађујућих тема и колористичко-валерских иновација које су нашле израз у англо-француској варијанти овог сликарског правца ${ }^{4}$. Стварајући под снажним

3 Оиене аустријског сликарства тог доба, посебно дела везаног за академију, једнодушне су. Оне указују да је у питању једно професионално гледано узорно сликарство, чија су се хтењ а и намере исирпьивале постизањем савршенства ликовне форме. Предуслов за такав однос према сликарству био је садржан у што бољем и потпунијем овладавању свим тајнама сликарске технике. Што су при томе прихватана средства и облици уметничког изражавања који су типични за реализам, питање је само уклапањ а аустријске уметности у опште токове европског уметничког стваралаштва друге половине XIX века. Када се то има у виду и када се зна да је Јовановић био и остао током целог свог стваралачког века привржен схватањима карактеристичним за ово раздобље аустријског сликарства, могу се тачније уочити његови уметнички циьеви. Наиме, све вредности и све мањкавости његовог сликарског дела проистичу из тога што је он, попут својих учитељь, веровао да ликовне вредности пре свега зависе од степена познавања вештине сликања - Момчило Моша Тодоровић (прир). (2009). Паја Јовановић, (прилог Николе Кусовца); Радионища душе, Београд, р. 35.

4 Непосредна близина Османског ияарства давала је бечком оријентализму приметне карактеристике 'alla turca', чији су стари и дубоки корени посађени у време када је Хабсбуршка 
утицајима с једне стране канонизованог сликарског поступка који је усвојио током свог школовања на Академији ликовних уметности, и утицајем који је на њега, преко породичне фотографске радње, извршио развој и усавршавање фотомеханичке репродукције, с друге стране, Паја Јовановић се, понајвише у портретном сликарству приближио некој врсти академског идеализма, а његово мишљење о непосредној евидентности сижеа једним пароксистичким преокретом довело је до одступања од реалистичког транспоновања лика у правцу његове званичне идеализоване форме.
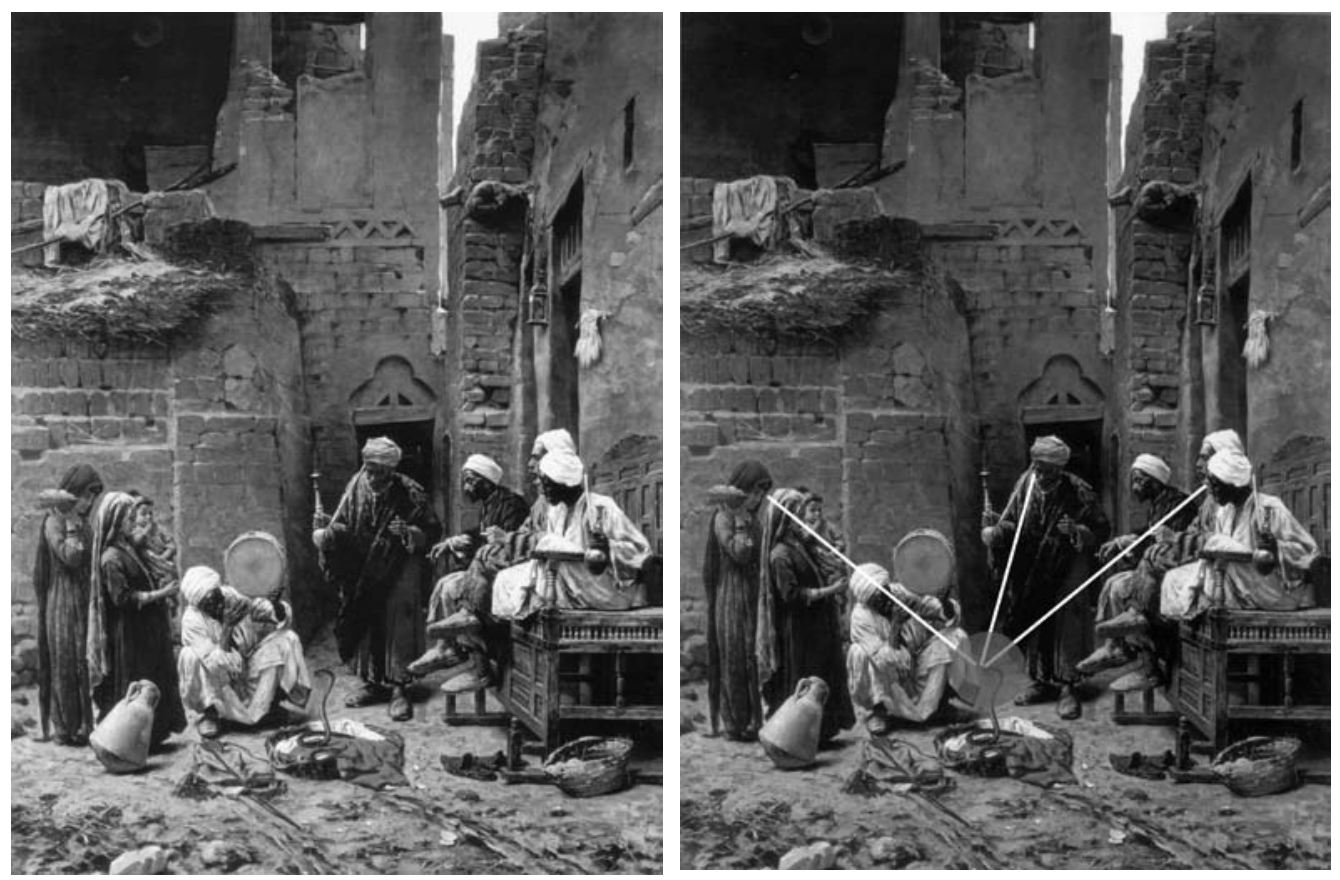

Укротитељ змија, 1887 - уље на платну, 107,3×83,2цм, збирка Шафир Габр, Каиро

Није никакво чудо што је Паја Јовановић као млад сликар, под јаким утицајем свог професора Милера, чије су преокупације биле управо теме везане за Египат, одлучио да приликом посете тој земљи на свом путовању на Блиски исток и у северну Африку, пренесе на платно и један од карактеристичних призора египатске свакодневице - демонстрирање умећа хипнотисања змије комбинацијом погледа и акустичких средстава (свирала или добош). Та слика је утолико специфична што

монархија себе сматрала бранитељем европског хришћанства. У време'fin de sciecle-а', он се отелотворио у моду такозваних 'Türkichen Zimmer', које се често срећу не само у палатама аристократије, него и у домовима више и средње класе. Блискост тако схваћеног Оријента традиционално се осећала чак и у популарној култури - Мирослав Тимотијевић. (2009). Паја Јовановић. Београд: Народни музеј у Београду, р. 72. 
представља и једину његову слику која тематизује неки аспект живота на Блиском истоку. Паја Јовановић се у тематско-мотивском погледу готово искључиво везивао за сликање призора из историје или свакодневног, оријентализованог, живота балканских народа, па чак су и она дела настала на основу скица које је сачинио на путовању на Кавказ у друштву Франца Алексејевича Рубоа (Franz Alekseyevich Roubaud) искључиво пејсажи, а не фигуралне композиције.

Посете „оријенталним“ земљама Блиског истока и северне Африке од стране сликара импресионистичке провенијенције нису имале сасвим безначајан утицај на њихове сликарске поетике, у којима развијају поставке о степену тонова и валерима као суштинским медијима транспоновања чисто окуларне, нерационализоване слике стварности, чиме су отворили пут за прелазак из већ догматизованих схема академског реализма у оне правце, који у европском сликарству обележавају другу половину XIX и почетак XX века - импресионизам, пленеризам, фовизам и др 5 . Несумњиво је да су атмосферски ефекти северне Африке оставили снажан утисак и на Пају Јовановића, што је јасно видљиво и у Укротитељь змија, међутим, тај утисак је убрзо избледео и није му, за разлику од поменутих сликара, послужио као основ за изградњу поетике која би знатније одступала од традираних образаца сликања које је усвојио на Академији лепих уметности. Утолико је тешко у потпуности се сложити с оценом да су у овој слици тема и форма, оно што чини основе академског сликарства, у потпуности [су] потиснуте, иако је тачно да највећи значај имају процес сликања, наномење боје, тежна да се забележи атмосфера места, колорит, светлост ${ }^{6}$. Чак и да је то желео, Паја Јовановић не би могао да напросто одустане од примене научених композиционих принципа, као што то никада нису учинили ни најпроминентнији импресионисти, зато што су ти принципи само у процесу акултурације усвојен формализован израз, на пољу ликовноуметничког стваралаштва, оних основних оријентационих просторновременских константи које представљају иманентне формативне чиниоце, остварене у низу својих стандардизованих формулација, од којих и академски реализам представља једну, него и у оним граничним субјективним или ширестилским настојањима ка његовом превазилажењу, превазилажењу које се, ипак, увек реализује као његово сопствено самопревазилажење, али никада и као његово безостатно укидање. Ма колико да колорит и ефекти светлости играју значајну

5 Последице тих посета очитују се у ьиховим ефектима на две велике области уметничког интересовања, тему и технику. Док се Жером, Луис и Бауернфајнд, на пример, редовно враћају карактеристичним призорима и темама Блиског истока, у случају Делакроаа, Фромантена, Реноара и Матиса, утицај Оријента манифестовао се у техничком аспекту юиховог развоја као сликара, посебно у њиховом оперисању светлошћу и бојом - Maryanne Stevens. (1984). Western Art and its Encounter with the Islamic World; u: Maryanne Stevens (ed). The Orientalists. London: Royal Academy of Arts, p. 15.

6 Мирослав Тимотијевић. (2009). Паја Јовановић. Београд: Народни музеј у Београду, pp. 83-84. 
улогу у Укротитељу змија, они не успевају да прикрију тектоничку арматуру композиције, њену векторијалну центричност која јој обезбеђује драматски напон, ону иманентну временитост коју подразумева Албертијева историа - покрет који не мора нужно да се очитује као остварен у пиктуралном пољу, него може да буде присутан као мишљен у свом бивању-остваривим.

Ако пажљиво погледамо ту његову композицију, приметићемо њену тематску и оптичку концентрисаност која произлази из вештог вођења погледа дуж композиционих доминанти остварених у конвергентним дијагоналама. Дијагонала која у левој трећини слике повезује групу посматрача са кротитељем змије полази правцем погледа жене која држи корпу с воћем, наставља се у погледима жене и детета и, преко погледа кротитеља, завршава главом змије. Друга дијагонала се протеже од погледа човека с турбаном, који је постављен на прелаз од средине ка десној трећини слике до главе змије, док сноп дијагонала полази од погледа̂ посматрача који седе. Ти дијагонални правци, као динамички моменти композиције, положени су у оквир статичких момената визуелизованим у вертикалним линијама ивица зидова, наглашених усправним положајем чибука у руци човека с турбаном, који се надовезује на вертикалну линију састава зидова у другом плану. Назнаке хоризонталне схеме очигледне су у фрагменту фриза зида у другом плану слике, као и у линији дрвене греде довратка. Захваљујући том једноставном композиционом решењу, Паја Јовановић је успео да оствари оне колористичке ефекте који су својствени оријенталистичким екстеријерима, али и да уједно очува и стабилну класичну композициону схему коју је, не само захваљујући знањима стеченим у току академских студија сликарства, осећао као једино легитимно средство ликовног израза.
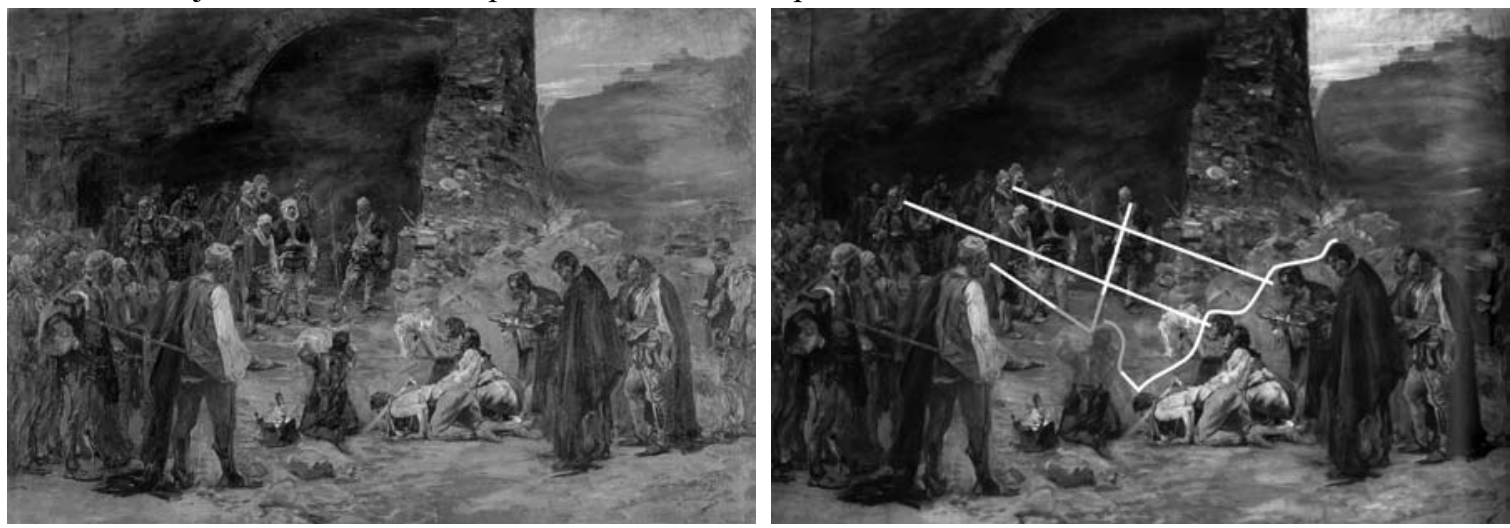

Умир крви (Крвна освета), 1889/1912 - уље на платну, димензије 137×95цм, Галерија Матице српске, Нови Сад 
Та слика, изведена у две варијанте, припада раном периоду Јовановићевог стваралаштва и улази у састав низа слика које приказују свакодневни живот, обичаје и занимања балканских народа. Треба имати у виду и чињеницу да оне, или барем већина њих, представљају имагинативну реконструкцију догађаја или, другачије речено, имагинативни топос који представља својеврстан стереотип о мишљењу и деловању народа̂ из тзв. „европске Турске“, настао у свести народа̂ западне Европе. Приказивање таквих, релативно лако препознатљивих призора, (гледалац је требало да без наслова чита шта слика прича), свакако је одговарало наручиоцима који су имали у виду укус публике у великим европским уметничким центрима, као и захтеве тржишта, те је у композиционе обрасце, на којима се од ренесансе па до друге половине деветнаестог века формирао укус те публике, требало унети нов и занимљив садржај, како би се комбиновањем страног и удаљеног с једне, и познатог и блиског, с друге стране, изазвала пажња и побудила радозналост. Напротив, Умир крви, као и остале Јовановићеве сижејне слике, у погледу структурирања наратива и фигуралне диспозиције, представљају саставни део традиције европског сликарства на којима оријентална костимографија и реквизити јесу само неиманентан додатак, израз дуга времену или неким специфичним интересима.

Ако се пажљивије размотре опште композиционе карактеристике ове Јовановићеве слике, лако ће се уочити његов однос према класичној традицији, заснован на дидактичким принципима аустријског академизма. Пиктурални простор јасно је диференциран у два међусобно координирана хоризонтална регистра. У горњем регистру приказана је група наоружаних људи, како из тамне позадине леве трећине слике ступа у средиште дуж дијагонално оријентисаног правца кретања од левог горњег ка десном доњем углу композиционе целине. Захваљујући контакту погледа̂ који успостављају протагонисти средишње групе горњег регистра са групом молилаца у десној трећини доњег регистра, дефинише се веома експлицитно и дијагонала као композициона доминанта, која у овом случају има и своју јасну симболичку функцију. Следећи однос елемената композиције јесте респективан положај жене у црвеној хаљини која клечи и држи дете у уздигнутим рукама, и особе на десном крају групе из горњег регистра, чији контакт погледом затвара оштар угао у односу на вертикалан положај штапа у њеној десној руци, штапа који репрезентује вертикалну осу композиције. Трећи формално-композициони моменат састоји се у линији, која се имплицитно повлачи од средишње особе у првом плану горњег регистра до мушкарца, који клечи држећи дете у рукама. Систем координата који произлази из дијагонале као доминанте, средишње вертикалне осе и две линије које их пресецају и одређују динамичке тенденције структурирања наратива, јесте образац класичног композиционог схематизма западне уметности. Дијагонална оријентација разбија 
статичност симетријски постављеног односа маса и указује на активитет деловања, његову циљну усмереност, истовремено симболички, указујући и на односе двају регистара, који су сада повезани не само вертикалним наслојавањем које указује на хијерархијски однос две групе људи, него и двојством активности и иницијативе, која лежи у рукама горње групе, и пасивности и самопорицања, својствених протагонистима у другој групи. Дијагонала као композициона категорија никада није идентична дијагонали као геометријском елементу, напротив, она, како је то Ханс Зедлмајр (Hans Sedlmayr) показао у својој анализи Бројгеловог (Piter Bruegel) дела Пад слепаца, има разноврсне функције - алегоријску, етичку и анагошку․․ Просторни поредак фигура̂ у поменутој слици одређује дијагонала, која је, поред осталих композиционих елемената, преузета из италијанског ренесансног сликарства, где ју је први користио Коређо (иако може да се уочи и у Ђотовој Noli me tangere у капели Скровењи), и која је у XVII веку потпуно потиснула рељефно наслојавање. Типичан пример Коређове употребе дијагонале као композиционе доминанте је његова слика Noli me tangere (cca. 1520), на којој се правац испружене десне руке Марије Магдалене, која клечи пред Христом, надовезује на усмереност њеног погледа који се сусреће са његовим и наставља преко његове испружене леве руке, завршавајући се у горњем десном углу слике. Већ овде, код Корећа, приметан је, не само композициони, него и емоционални динамизам, који произлази из овог дијагоналног распореда фигура и који не очитује намеру да ce нагласе теолошко-хијерархијски односи између протагониста̂ Новог Завета, него да се они превладају у предочавању једног анагошког стремљења које их све подједнако води. Разлика између дијагонале као композиционе доминанте у Коређовој Noli me tangere и Бројгеловом Паду слепаща, сведочи о суштинском значају ове композиционе оријентације за разумевање уметничког дела уопште. Код Корећа дијагонала, наиме, полази из доњег левог угла, водећи поглед од грешне приземности која тражи искупљење, оличене у Марији Магдалени, ка Христу као Искупитељу који јој указује на небеску милост и тиме евоцира културално индуковану непосредност оријентисања у простору, која подразумева идентификовање нижег са мање вредним положајем, као и правца кретања навише са успоном или избављењем из неке невоље. Напротив, у Бројгеловом Паду слепаца, дијагонала полази из горњег левог ка доњем десном углу и тако изражава опажајни карактер злокобне слутње пред неизбежном пропашћу ${ }^{8}$.

7 Cf. Hans Sedlmayr. (1985). Pieter Bruegel: Der Sturz der Blinden; u: Epochen und Werke (Gesammelte Schriften zur Kunstgeschichte). München: Erster Band, Mäander, pp. 319-357.

8 Тако се на динамичком и контрапостном деловаюу барокне просторне дијагонале изграђује један грандиозан трагизам. Као што је она оштро и неумољиво супротстављена лепом току линија и хармоничном распореду маса̂ пејсажа, тако с друге стране тихо спокојство и непокретан мир овог пејсажа делује као јасна супротност овој судбинској катастрофи, која се у њему дешава - Max Dvořák. (1928). Pieter Breugel der Ältere; u: Kunstgeschichte als 
Ако дијагонала као доминанта одређује структуирање наратива у читавом његовом обиму, тј. у целини пиктуралног простора ове Јовановићеве слике, онда линије засноване на комуникацији погледа - назовимо их а' и б' и а" и б" - одређују својом тачком пресека, не само тематско, него и оптичко средиште композиције. Када бисмо описали круг, чије би средиште лежало у тачки пресека ове две линије, а обим кружнице одређивале полазне и завршне тачке наведених линија, тим поступком уоквирили бисмо оно што, преузимајући Арнхајмов (Rudolf Arnheim) термин, називамо микротемом композиције, као средиштем у коме конвергирају сви одређујући оријентациони правци и из кога, следствено, полазе и векторски правци (у које спада и дијагонала), као динамички чиниоци композиције 9 . Отуда је овде остварен принцип комплементарности праваца супротних оријентација и успостављена хармонијска равнотежа композиционих елемената.

Поред тих карактеристика, које осим припадности поменутој традицији, сведоче и о несумњивом мајсторству у владању принципима и техником сликарства у његовом класичном изразу, треба указати на још један начин коришћења линије као средства драматизације сижеа и истицања значаја појединих представљених ликова. Ако се пажљиво размотри положај фигура у десној трећини Умира крви, примећује се да је њихов распоред такав да прати линију која полази од фигуре у смеђем огртачу у предњем плану, прелазећи затим преко клечећих фигура жене и мушкарца с дететом, спуштајући се до нивоа главе мушкарца у полулежећем положају с мачем привезаним за врат, да би се почев отуда нагло подигла и завршила у висини главе жене у црвеној хаљини. Та крива упућује на оријентациони правац комплементаран правцу који заступа дијагонална доминанта. Употреба валовите линије као средства концентрисања пажње на тематско језгро композиције представља још један манир класичног сликарства, који може да се пронађе још у Рафаеловом (Raffael Sanzio) Чудотворном риболову, једном од картона за гоблене који је требало да стоје испод Микеланђелових фресака у Сикстини. Велфлин (Heinrich Wölfflin) је уочио да постоји намера да се наглим падовима и успонима погледа који прати развој теме укаже на значај појединих ликова и с правом каже да смо задивљени умијећем којим су сви рибари у чамичима сведени под једну велику линију, која почиюе код веслача, а диже се преко сагнутих ликова, те досиже највећу тачку у фигури која стоји, затим се нагло спушта тако да се

Geistesgeschichte. München: Piper\&Co. Verlag, p. 247.

Cf. Радован Поповић. (2009). Херменеутичка и структуралистичка теорија визуелног текста (diss), Београд: Универзитет уметности, pp. 127-168.

9 Равнотежни центар слике често заузима акиија која у малом одражава и симболизује тему читавог дела. Ова симболичка репрезентација... тежи да представља редуктивну апстракиију која може да саопшти тему у концентрисаној непосредности - Rudolf Arnheim. (1983). The Power of the Center. A Study of Composition in the Visual Arts. Los Angeles: University of California Press, p. 94. 
на завршетку још једном подиже код Криста. Све води до њега, он представља ииљ кретања. Премда је као маса незнатан и потиснут до руба слике, он ипак влада над свима ${ }^{10}$. Није потребно уложити много напора па да се увиди како Паја Јовановић преузима и вешто користи овај композициони моменат акцентуације значаја жене, која као најснажнији аргумент за обустављање крвне освете истиче невиност новорођеног детета за кривицу родитеља и потребу поштеде живота његовог оца, који у ставу најдубље понизности представља у исто време и тачку инфлексије из које линија наглим успоном води око посматрача ка средишњој фигури групе у доњем регистру.
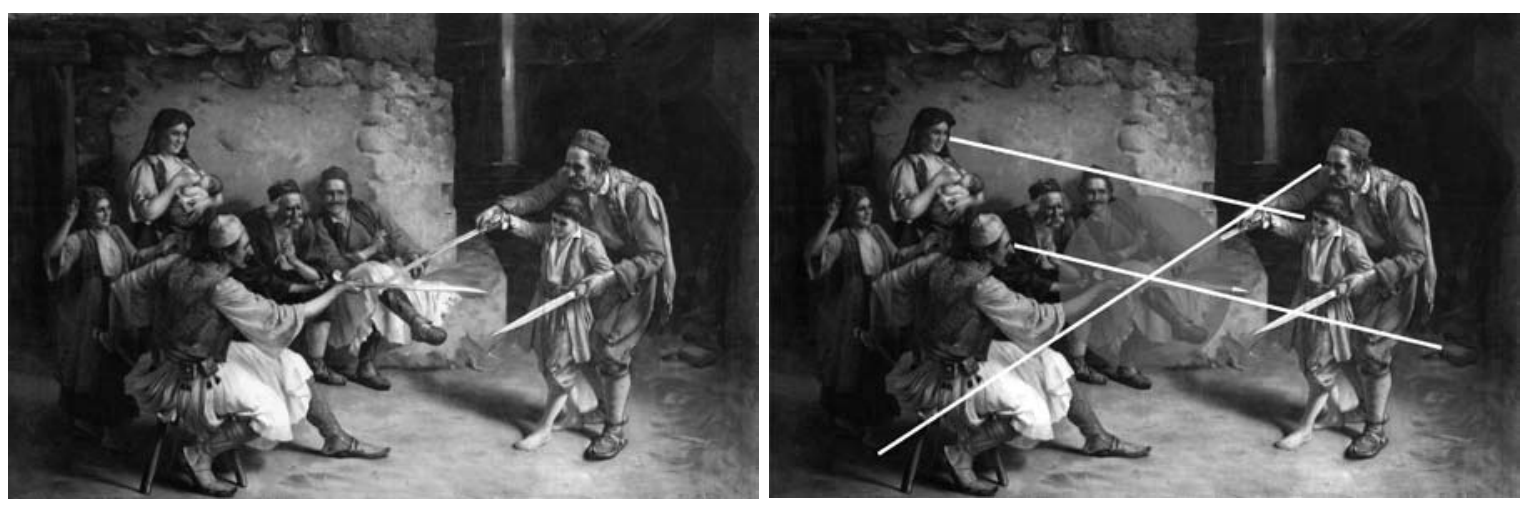

Мачевање, верзија из сса. 1900 - уље на платну, димензије 100×150цм, приватно власништво

Сликовит пример патриотског тумачења наратива слике је опис у тексту Мите Живковића, настао уз сликареве сугестије: "Црногорска сељачка соба, отац сео на клупицу, да поучи свога синчића у мачевању. Дечко слаб, једва држи ханџар. Досади се деди гледати га, остави запаљену цигарету на клупу, па узме унука преда се, десницом му ухватио слабачку десницу, у којој је ханџар, па му показује, како да напада и како да се брани; бабо укрсти ханџар са синовљевим, па ужива, како му син пажљиво прати покрете. У средини седе два суседа и - млађи с осмехом, а старији с озбиљношћу - прате ову очигледну наставу. Поред њих мајка дечакова доји детенце и с блаженим осмехом гледа, како јој се првенац спрема да свети Косово; крај ње кћерка јој пуцка прстима од радости, што јој братац тако напредује". ${ }^{11}$

Горњи опис Мачевања, осим што у основним цртама пружа представу о фигуралним координатама композиције, у својој романтичарско-патриотској тенденциозности, покушајем да на један површан начин протумачи психолошку

10 Heinrich Wölfflin. (1969). Klasična umjetnost. Zagreb: Matica hrvatska, p.75;

11 Живковић, М. (2009). Паја Јовановић академски сликар; цит. из Мирослав Тимотијевић.

Паја Јовановић; Београд: Народни музеј у Београду, pp. 81-82. 
мотивацију и временски редослед поступака приказаних личности - све оно што се у визуелном тексту не садржи, него се у њега уноси накнадном интерпретативном интерполацијом - као и да подвлачењем типизираних ставова потврди патријархалну родну диференцијацију друштвених улога и положаја, не може знатније да допринесе увиду у дискрепанцу која постоји између приказа једног у већини аспеката оријентализованог друштва, какво је било црногорско друштво у XIX веку, и његове ликовноуметничке транспозиције у обрасце класичне европске уметности. Као и у случају описа његових историјских композиција, реч је о идеологизованој варијанти класичког екфразиса, онаквог какав може да се нађе у путописним или популарнонаучним делима антике, посебно код Паусаније (Pausanias), Плинија Старијег (Plinius Maior), Филострата (Philostratus) и других ${ }^{12}$. Оно што је значајно обележје композиционог решења ове слике јесте, међутим, њена изразита структурална правилност и наглашена схематизација координатног поља. Основни геометријска мрежа осигурана је двема паралелним вертикалама датим у перспективној пројекцији, које се визуелизују у правим линијама зидова огњишта. Ова вертикална оса манифестује се и у осветљеном правоугаоном појасу у позадини, којим се вертикална оријентација композиције перпетуира у десну трећину слике, а функцију вертикалне осовине у левој трећини преузима стојећа фигура жене која доји дете и чији скулптурални, каријатидални став је знатно израженији у студији оловком, рађеној око 1883. г. У хоризонталној мрежи композиције може да се сагледа умеће Паје Јовановића да пронађе карактеристична решења, али и лакоћа и непроблематичност с којима је третирао овај проблем. Хоризонтала је, наиме, повучена читавом дужином кровне греде која покрива узан појас простора дуж горње ивице слике, паралелно којој до половине тече линија која се поклапа са горњом ивичном линијом огњишта. Исту функцију има, нешто ниже, и латентна комуникација погледом дечака и његове сестре. Тиме је постављен и основни схематски оквир у који се уписују фигурални елементи, који, такође, представљају носиоце две дијагоналне доминанте различитог правца које се секу у тачки додира мачева које су укрстили отац и син. Дијагонална пројекција, полазећи из горњег левог угла, прати линију погледа која се пружа од лица мајке с дететом, на коју се надовезује поглед старца који седи погнут према микротематском средишту композиције, допире до тачке у којој се пресецају сечива двају мача и хипотетички се завршава у доњем десном углу слике. Конвергентан дијагонални правац, који је још јасније назначен елементима композиције, има своје исходиште у погледу старца који придржава

12 'Ekphrasis' је поникао у позној антици као реторичко средство похвале и описивања људи, места̂, грађевина и уметничких дела. Најранији пример таквог представљань уметничког дела је Хомеров Ахилејев штти - Svetlana Leontief Alpers. Ekphrasis and Aesthetic Attitudes in Vasari's Lives. Journal of the Warburg and Courtland Institute(s), Vol. 23, No. 3/4 (Jul. - Dec., 1960), p. 196. 
руку дечака, продужава се линијом његове десне руке и даље, преко мача који у тој руци држи, хипотетички се протеже све до доњег левог угла слике. Није тешко утврдити да мач који у хоризонталном положају држи дечаков отац затвара прав угао с вертикалном линијом материјализованом у ивичној линији споја два зида огњишта. Коначно, ако бисмо желели да демонстрирамо формалну целовитост и класично савршенство ове Јовановићеве композиције, могли бисмо да око протагониста приказаног призора опишемо круг, чије би се средиште налазило у тачки пресека мачева. Круг је, још од антике, а посебно у доба ране ренесансе, имао изузетан статус идеалног геометријског тела, које је уз то садржавало и симболичко-мистичку полисемију, као место сусрета микрокосма и макрокосма, али сличност централног плана са кружном формом индоевропских кућа, које архитектонски транспонује кружни распоред седења око ватре (огњишта) $)^{13}$. Ако се пажња задржи на микротеми, коју добијамо када, полазећи од средишта, опишемо кружницу полупречника мањег за две трећине од прве, приметићемо да статичку равнотежу композиције коју обезбеђује пресек вертикале и хоризонтале нарушавају дијагонално постављени векторски правци, али тако да се, за разлику од Умира крви у коме постоји само једна изразита композициона доминанта, овде две дијагонале у узајамној конвергенцији уравнотежују, тако да композиција оставља утисак притајеног сукоба и неизвесности ишчекивања, чиме се строга симетријска равнотежа која произлази из наглашене схематске основе вертикалнохоризонталних пресека, превладава хармонијским динамизмом међусобног уравнотежавања. Привидно неравномеран распоред маса (три фигуре у левој, две у средишту и две у десној трећини слике) решава се маестралним ритмичким обрасцем иступања левом ногом деде и унука ка предњем плану уз истовремено рецедентан положај сестре и мајке ка другом плану.

Круг као форма структурирања не само композиције у њеном формалном изразу него и самог пиктуралног наратива, може да подстакне интензификовање пажње коју треба усмерити на неки ексцентричан моменат сижеа или неки иконографски

13 Такође сазнајемо о утешитељском ефекту круга, јер 'сагледавајући круг, поглед све обухвата у тренутку, без прекида или препреке' (Филарете) Тако је Албертијево космолошко разматрање кружног облика овде замењено психолошким и визуелним приступом и од сада геометрија круга игра још истакнутију улогу. Франческо ди Ђорђо засновао је своју препоруку градитељима иркава на емпиријском закључивању: он је заступао мишљење по коме безброј типова постојећих иркава може да се сведе на три основна: прво, на кружан облик за који је говорио да је најсавршенији (подв - Р.П), друго, на правоугаони, и треће, на юихову комбиновану форму... С оживљавањем грчког математичког објашњења бога и света у Ренесанси и подстакнуто хришћанским веровањем да човек као слика бога отеловљује хармонију универзума, витрувијевска фигура уписана у квадрат и круг постала је симбол математичке сродности микрокосма и макрокосма. Како је на бољи начин могао бити изражен однос између бога и човека...него градњом божје куће у складу с фундаменталним геометријским односом квадрата и круга? - Rudolf Wittkower. (2002). Architectural Principles in the Age of Humanism, New York - London: W.W.Norton\&Co, pp. 10-11, 16. 
детаљ. Циркуларност композиције, како је Арнхајм правилно приметио, може да нагласи деловање картезијанске решетке као универзалне физиолошко-оптичке рецептивне матрице управо снажном иманентном везом елемената композиције. То дејство најизразитије је у формату тонда, који и самом формом пројективне равни појачава овај ефекат ${ }^{14}$.
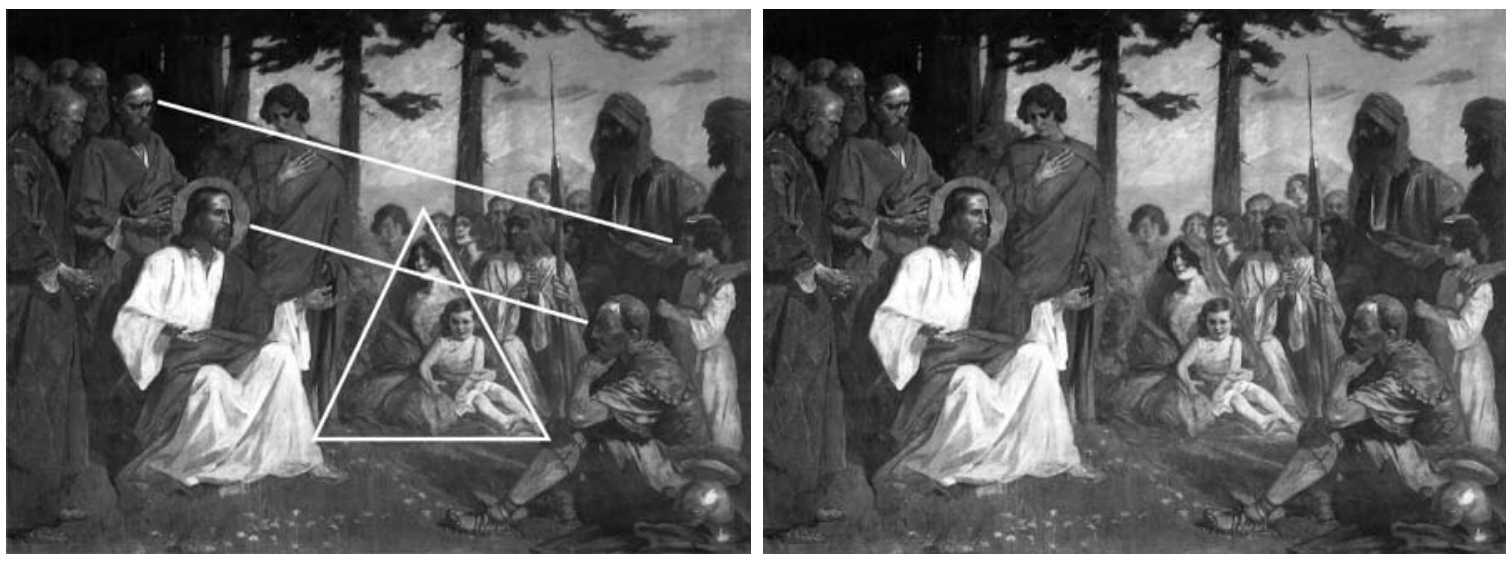

Христова проповед на Гори, цца. 1909 - уље на платну, димензије 272,5×200цм, Саборна црква у Сремским Карловцима

Та слика настала је као део циклуса слика̂ с религијским темама наручених од стране Српске православне цркве у склопу реконструктивних радова који су започети 1907. г. Пажљиво компонована дистрибуција маса, наглашено поштовање принципа централне перспективе, колористички ефекти као средство акцентуације значаја приказаних личности, карактеристични ставови фигура - све ово представља јасан показатељ темељне изграђености традиционалних вештина компоновања наратива у „историјским“ сликама, као и парадигматичан пример сувереног владања сликарском техником. Прецизна реконструкција одеће, војничке опреме и оружја римског војника, који је приказан у седећем ставу у доњем десном углу слике, као и разлика у одећи између локалног становништва и апостола̂ упућују на правила о етнографској верности приказаних садржаја која је Паја Јовановић, као саставни део правила̂ немачког „историцистичког“ сликарства, прихватио још у својим формативним годинама, током школовања на Академији лепих уметности. Композициона структура слике почива на експлицитној геометријски правилној основи, која се састоји у правоуглом

14 Померање основних момената из средишта представљь другу функиију активизаиије композиције.. Средиште може да остане неназначено само по себи, али може да служи као основа или акценат за мелодију активности. Та улога средишта снажно је подстакнута кружним форматом тонда - Rudolf Arnheim. (1983). The Power of the Center. A Study of Composition in the Visual Arts. Los Angeles: University of California Press, p. 128. 
пресеку визуелизованих и невизуелизованих вертикалних и хоризонталних линија. Вертикале се, без битнијих одступања, поклапају са осовином стабала приказаних на левој и средишњој трећини слике, те са правцем копља које држи римски војник у десној трећини слике. Невизуелизоване односно неексплицитне хоризонтале конституишу се у равни која додирује темене делове глава стојећих фигура, као и у комуникацији погледом између Христа и девојчице у десној трећини слике. Динамички моменти композиције знатно су сложенији од ових морфолошких, међутим, и они остају у сагласности са правилима геометризованог приказивања респективних односа и положаја фигура, онако како су они формулисани још у периодуране ренесансе. Наиме, ако се обрати пажња на десну трећину композиције, лако се уочава да континуитет усмерености погледа̂ приказаних апостола, почев од позадине па до другог плана, конституише дијагоналну смерницу која се завршава главом Христа, док смер погледа двају ученика приказаних у стојећем ставу иза Христових леђа затварају, са завршном тачком на Христовој глави, угао од око $30^{\circ}$, чиме се, једноставним повлачењем праве линије од главе једног до главе другог апостола, добија форма једнакостраничног троугла - форма, која, поред осталог, представља и симбол Светог Тројства, који се, као иконографски детаљ, у виду ореола око главе Бога Оца, налази и на његовој олтарској икони која приказује Свето Тројство у Саборној цркви у Новом Саду (1903-1905). То, међутим, није и једини део композиције у коме је троугао као композициони моменат присутан. Он, такође, постоји и у форми граничне линије жене која седи и у крилу држи дете, али и у положају помињаног римског војника, чија нога, савијена у колену, на коју се непосредно надовезује надлактица леве руке, не оставља никакве сумње у намеру уметника да композицији осигура стабилност посредством ових тектонских композиционих образаца. У коликој мери ова решења показују изразит утицај композиционих принципа Запада, коме Јовановић, а и читаво српско сликарство, суштински припадају, очигледно је ако се положаји поменутих фигура упореде са карактеристичним положајима фигура са Ђотових (Giotto) фресака у Капели Скровењи, првим примерима девизантинизованог сликарства на Западу. Очигледни, могли бисмо да кажемо и парадигматски, примери овог положаја, представљају положај фигуре Јоакима на фресци Јоакимов сан, у првом регистру десног зида капеле, на коме су приказани призори из Маријиног живота, Маријин став у Благовестима у десном доњем крају лунете која наткриљује улаз у апсидални део капеле, као и фигура уснулог Јосифа у приказу Христовог рођења у циклусу призора из Христовог живота (други регистар десног зида). То је, дакле, традиционалан типичан положај који, осим композиционе, има и симболичкорефлексивну вредност, указујући на спокојство, стабилност, извесност, исто онако као што у композиционом погледу оснажује статичност приказа ${ }^{15}$. Динамички

15 Ништа не треба да поремети Јоакимов сан. Смирен период заборава у драми која га погађа.

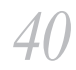


чиниоци, осим поменуте дијагоналне линије, која се додирује са дијагоналом која прати поглед слушаоца у окер-црвеном огртачу у десној трећини слике, завршавајући се на Христовом лицу, не представљају композиционе окоснице слике, не само због благог пада дијагоналних праваца, него и због њиховог узајамног поништавања у тачки додира.

Композиција је, дакле, изразито статички диспонирана, иако не и схематски и неинвентивно мишљена. И поред примене централне перспективе, с тачком недогледа мало изнад главе жене која седи у средишњој трећини слике, она, разуме се, не представља и тематско средиште композиције. Зато је Паја Јовановић прибегао једном композиционом моменту који је у европском сликарству познат од периода маниризма (нпр. Тинторетова Тајна вечера) $)^{16}$, а то је измештање оптичког из геометријског средишта композиције. На тој Јовановићевој слици, за разлику од Тинторетове, линије перспективе секу се у геометријском средишту пиктуралног простора, док је фигура Христа постављена лево од тог средишта. Међутим, субјективно-оптички доживљај осциловања средишта композиције је истоветан. Паја Јовановић је, да би нагласио средишњи тематски значај Христове личности, користио и веома чист и вибрантан тон белог за Христову тунику, која је снажно контрастирана отворено-црвеном његовог огртача, а све то уписано је у једноличну и загаситу окер подлогу одора апостола. Тај ефекат колористичке интерференције истичу и симболичка значења која бело и црвено имају у хришћанској иконографији ${ }^{17}$ и управо он доприноси истицању средишње личности наратива.

То је час небеске поруке, у коме златни ореоли заменују безвремене речи. Ту, где се завршава неспокојно бдење људског сриа, отвара се један нов пут - Claudio Bellinati. (2003). Giotto Guide iconographique de la Chapelle des Scrovegni. Treviso: Vianellolibri, pp. 34-35;

16 Естетске и симболичке импликације тог Тинторетовог дела разјашњава Арнхајм у својој сјајној анализи: На једној Тинторетовој представи Тајне вечере... насликаној шездесетак година после Леонардове, жижа собе, успостављена линијама стола, пода и таванице, лежи у горњем десном углу. Али средиште приче је фигура Христова. Ексиентричност простора показује да је закон тог света изгубио своју апсолутну вредност. Она је приказана као један начин постојања међу многим другим, подједнако могућим. Њен нарочити 'нагиб' открива се оку, а радња која се одиграва у том спрегу тражи сопствено средиште и сопствена мерила пркосећи склопу иелине. Појединачна радња и владајући ауторитет постали су опречни саучесници који уживају једнака права. У ствари, овде Христова фигура држи средиште спрега, бар што се тиче хоризонталне равни, тако да се, одступајући од захтева околног света, појединац приближава положају апсолутне важности - што је преокрет који одражава дух новог доба - Рудолф Арнхајм. (1998). Уметност и визуелно опажање. Београд: Универзитет уметности у Београду, Студентски културни центар, p. 251.

17 Најзад, хришћански сликари средњег века приказују Вечнога одевеног у бело, као и Исуса Христа после ускрснућа... У сакралном језику Библије бела одећа је симбол препорода душе и награда изабранима. Онај који ће победити, каже се у Апокалипси, биће одевен у бело и нећу никада избрисати његово име из књиге живота... Љубав могу да осете само девствене душе и невини. Краљевство небеско, каже Исус Христ, показује се онима који личе на деиу. У паганској антици, ирвено је било симбол невиности и девствености. - Portal, Frédéric. (1991). Des couleurs simboliques dans l'antiquité, le moyen-age et les temps modernes. Paris: Éditions de la Maisnie, pp. 45, 117. 
Све наведене композиционе и колористичке карактеристике ове слике Паје Јовановића - која, заједно са многим другима које је насликао за Саборну цркву у Новом Саду, није наишла на одушевљен пријем познавалаца због (наводне) неприпремљености с којом је приступио раду, док се, по овим мишљењима, формално окретање ка старом начину сликања може се тумачити као његово носталгично призивање прошле славе, као нада да се враћањем на проверене u потврђене вредности могу васкрснути некадашњи сјај и углед ${ }^{18}$ - јасно и недвосмислено указују на његову неугаслу уметничку снагу. У сликању таквих тема, у одмерености покрета и чистоти тонова (треба нпр. упоредити његовог Архиепископа ДаниласаХантовом Светлошћусвета даби сеувиделеовесличности, као и мајсторство у коришћењу контролисане светлости), осим тога, има и неке прерафаелитске величине, неке спокојне сабраности и инспиративности, које тим Јовановићевим религијским сликама осигурава трајну уметничку вредност.

Паја Јовановић је умро крајем новембра 1957, овенчан многим признањима и наградама, које је током свог дугог стваралачког века заслужено добијао. Међутим, он је већ у периоду после 1905. био изложен оспоравањима и критикама, које су се кретале од компетентних разматрања његовог академизма, који је већ тада био доживљаван као ствар прошлости, па до злонамерних напада ад хоминем, који су доводили у питање и личне мотиве његовог рада, посебно у области портретног сликарства, као и уметничку испразност коју је, наводно, прикривао техничком виртуозношћу ${ }^{19}$. Упркос томе, Паја Јовановић је успео да докаже да познавање технике и правила компоновања често може да представља основ за вреднија уметничка остварења од пуке иновативности, утолико што техника и принципи сликарства произлазе из традиције која у својим историјским манифестацијама, увек налази свој савремен израз.

18 Тодоровић, Момчило Моша. (2009). Паја Јовановић. (прилог Николе Кусовца); Радионица душе, Београд, р. 99.

19 Тадић, Сf. Дејан. (2009). У песми боја. (Белешке о животу и раду Паје Јовановића). Београд: IP Book, pp. 79-80. 


\section{Литература:}

Alpers, Svetlana Leontief. (1960). Ekphrasis and Aesthetic Attitudes in Vasari's 'Lives'; Journal of the Warburg and Courtland Institute(s), Vol. 23, No.3/4 (Jul. - Dec. 1960) Арнхајм, Рудолф. (1997). Уметност и визуелно опажане. Београд: Универзитет уметности у Београду, Студентски културни центар.

Arnheim, Rudolf. (1983). The Power of the Center. A Study of Composition in the Visual Arts. Los Angeles: University of California Press.

Bellinati, Claudio. (2003). Giotto - Guide iconographique de la Chapelle des Scrovegni. Treviso: Vianellolibri.

Claesges, Ulrich.(1964). Edmund Husserls Theorie der Raumkonstitution. Den Haag: Martinus Nijhof.

Dvořák, Max. (1928). Kunstgeschichte als Geistesgeschichte. München: Piper\&Co. Verlag,

Francastel, Pierre. (1965). Peinture et société. Paris: Gallimard.

Frankastel, Pjer. (1964). Umjetnost i tehnika. Beograd: Nolit.

Кусовац, Никола. (1979) Паја Јовановић - слике великог формата. Београд: Народни музеј у Београду.

Lapique, Charles. (1958). Essais sur l'espace, l'art et la destinée. Paris: Éditions Bernard Grasset.

Поповић, Радован. (2009). Херменеутичка и структуралистичка теорија визуелног текста (diss). Београд: Универзитет уметности.

Portal, Frédéric. (1991). Des couleurs simboliques dans l'antiquité, la moyen-age et les temps modernes. Paris: Éditions de la Maisnie.

Sedlmayr,Hans.(1985).Epochenund Werke(GesammelteSchriftenzur Kunstgeschichte) Bd. I. München: Mäander.

Stevens, Maryanne (ed). (1984). The Orientalists. London: Royal Academy of Arts.

Тадић, Дејан. (2009). У песми боја (Белешке о животу и раду Паје Јовановића). Београд: ИП Book.

Тимотијевић, Мирослав. (2009). Паја Јовановић. Београд: Народни музеј у Београду.

Тодоровић, Момчило Моша (прир). (2009). Паја Јовановић; Радионииа душе, Београд.

Wittkower, Rudolf. (2002). Architectural Principles in the Age of Humanism., New York - London: W. W. Norton\&Co.

Wölfflin, Heinrich. (1969). Klasična umjetnost. Zagreb: Matica hrvatska. 


\section{The analysis of formal compositional characteristics of orientalist paintings by Paja Jovanović}

Abstract. Paja Jovanovic's painting developed all its important characteristics in the late seventies and early eighties of the $19^{\text {th }}$ century, during the time span in the history of European art which is considered to be a constitutional period for the development of poetics in painting such as impressionism, en plein air painting, pointillism and symbolism, which in the terms of composition, colouration and the use of light transformed profoundly the mimetic patterns and traditional techniques of atelier approach to the model and took painting from its self-imposed isolation into a pulsating reality of unbridled elements and human passion, already determined not only by centuries-old subject matters crystallised in "eternal" conflicts of duty and honour, love and self-sacrifice, individual parvenuism and altruistic devotion, but more often by the directing of the autonomous and technicised reason, which started in the late $18^{\text {th }}$ century its victorious pace to mastering and utilisation of its available sources hidden in once sacralised nature, guided by Bacon's formula "Knowledge is power." Numerous journeys in oriental regions of the Balkan Peninsula, and research travels in the Caucasus Mountains and Egypt, provided Paja Jovanovic with a direct insight into inexhaustible abundance of iconographic details and motifs which were to be introduced later into his orientalist works.

Key words: orientalism, the Balkans, impressionism, composition, colouration 


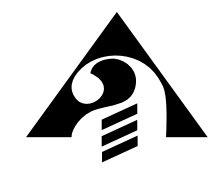

УНИВЕРЗИТЕТ У НОВОМ САДУ АКАДЕМИЈА УМЕТНОСТИ 